\title{
STATUS KARIES ANAK USIA PRASEKOLAH SEKOLAH CITRA KASIH YANG MENGONSUMSI SUSU FORMULA
}

\author{
${ }^{1}$ Aprilia Lombo \\ ${ }^{2}$ Nelly Mayulu \\ ${ }^{3}$ Paulina N.Gunawan \\ ${ }^{1}$ KandidatSkripsiProgramStudiPendidikanDokterGigiFakultasKedokteran \\ Universitas SamRatulangiManado \\ 2Bagian Gizi Fakultas Kedokteran Universitas Sam Ratulangi Manado \\ ${ }^{3}$ Program Studi Pendidikan Dokter Gigi Fakultas Kedokteran \\ Universitas Sam Ratulangi \\ Email: prilia.lombo@gmail.com
}

\begin{abstract}
Caries is disease on dental hard tissue that causes cavity in the tooth and on children is called rampant caries. Rampant caries occur because of the children who consume cariogenic foods and beverages as well as lack maintenance of oral hygiene. Formula milk is one of the food product that contain high nutritional value but can cause caries in children due to lack of proper feeding patterns like the duration of intake, frequency, duration, manner of presentation and means of prevention. The purpose of this study was to describe the caries status of preschool children in the Citra Kasih School who drink formula milk. This was a descriptive research with cross sectional study methods. The sample in this study amounted to 53 respondents with a total sampling technique based on the inclusion criteria.The results of caries status in children at school Citra Kasih Manado age 2-5 years old showed results d (decay) 36 respondents, e (Indicated for extraction) 29 respondents, and f (filled) 19 respondents, while based on formula milk feeding patterns obtained results the majority of preschooler students at Citra Kasih School Manado consume formula $>2$ years, the frequency of drinking milk $>3$ times daily, duration of drinking milk $\leq 15$ minutes, without the addition of sugar, and not given water after consuming milk formula, and with an average def-t value of 1,6 according to the assessment def-t indicators from the WHO.Caries status of preschool children in the School Citra Kasih Manado who drink formula milk was classified in the low category.
\end{abstract}

Keywords: caries status, preschoolers, formula milk

\begin{abstract}
Abstrak: Karies merupakan suatu penyakit jaringan keras gigi yang menyebabkan kavitas pada gigi dan pada anak-anak disebut rampan karies. Rampan karies terjadi karena pola konsumsi makanan dan minuman yang bersifat kariogenik serta kurangnya pemeliharaan kebersihan gigi dan mulut anak. Susu formula merupakan salah satu produk makanan yang mengandung nilai gizi yang cukup tinggi namun dapat menyebabkan karies pada anak akibat pola pemberian yang kurang tepatseperti lama pemberian, frekuensi, durasi, cara penyajian dan cara pencegahan. Tujuan penelitian ini ialah untuk mengetahui gambaran status karies anak usia prasekolah di Sekolah Citra Kasih yang mengonsumsi susu formula.Penelitian ini merupakan penelitian deskriptif dengan metode pengambilan data yaitu cross sectional study. Sampel pada penelitian ini berjumlah 53 anak yang diperoleh menggunakan teknik total sampling sesuai kriteria inklusi.Hasil penelitian menunjukakan indeks def-t rata-
\end{abstract}


rata anak yaitu 1,6 dengan nilai d (decay) 36, e (indicated for extraction) 29 , dan $\mathrm{f}$ (filled) 19. Berdasarkan pola pemberian susu formula diperoleh hasil, mayoritas murid sekolah Citra Kasih Manado mengonsumsi susu formula $>2$ tahun, frekuensi minum susu $>3$ kali sehari, durasi minum susu $\leq 15$ menit, tanpa adanya penambahan gula dan pemberian air putih setelah mengonsumsi susu formula.Status karies anak usia prasekolah di Sekolah Citra Kasih Manado yang mengonsumsi susu formula tergolong dalam kategori rendah.

Kata kunci: Status karies, anak usia prasekolah, susu formula

Karies merupakan suatu penyakit pada jaringan keras gigi, yaitu email, dentin, dan sementum yang disebabkan oleh aktivitas suatu jasad renik dalam suatu karbohidrat yang dapat difermentasikan.Karies yang terjadi tiba-tiba dan menyebar secara cepat pada anak-anak disebut rampan karies.Rampan karies seringkali terlihat pada anak-anak di bawah usia enam tahun yang mempunyai kebiasaan minum susu formula menggunakan media botol susu. ${ }^{1}$

Susu formula merupakan suatu produk makanan yang mengandung nilai gizi cukup tinggi, karena sebagian besar zat gizi esensial seperti protein, kalsium, fosfor, vitamin A, dan vitamin B1 ada di dalam susu formula.Tambahansusu formula dalam pola konsumsi anak sangat dianjurkan untuk melengkapi kebutuhan zat gizi dan nutrisi anak bagi pertumbuhan dan perkembangan. ${ }^{2}$ Namunterkadangpemberian susuformulainimalahan menimbulkan masalah bagi kesehatan anak, salah satunya berkaitan dengan kesehatan gigi dan mulut anak.Pola konsumsi susu formula yang kurang tepat seperti cara penyajian yang menggunakan botol yang dihubungkan dengan lama pemberian, frekuensi, dan waktu pemberian dapat menyebabkan terjadinya karies pada anak.

Data WHO tahun 2003 menggambarkan bahwa angka kejadian karies pada anak sekitar 60-90\% kasus. ${ }^{3}$ Anak usia 4-5 tahun yang tinggal di pedesaan mengalami $95,9 \%$ kejadian karies, dengan nilai def-t (decayed, extracted, filled, tooth) 7,98 dan anak yang tinggal di perkotaan mengalami 90,5\% kejadian karies, dengan nilai def-t 7,92.Menurut Community Dental Oral Epidemiology anak-anak usiaTK di Indonesia mempunyai resiko besar terkena karies. ${ }^{4}$
Sekolah Citra Kasih merupakan salah satu sekolah swasta yang berada di kota Manado. Sekolah ini memiliki beberapa jenjang pendidikan, di antaranya playgroup dan taman kanak-kanak. Berdasarkan survei awal sebagian besar anak-anak usia prasekolah (2-5 tahun) berada pada jenjang pendidikan playgroup dan taman kanakkanak. Informasi lainnya yang ditemukan menunjukkan bahwa beberapa anak pada usia ini telah memiliki karies pada beberapa giginya terutama gigi anterior dan masih mengonsumsi susu formula.

Berdasarkan latar belakang di atas, maka penulis merasa tertarik untuk melakukan penelitian tentang "Status Karies Anak Usia Prasekolah Sekolah Citra Kasih yang Mengonsumsi Susu Formula". Penelitian ini merupakan penelitian pertama yang dilakukan di sekolah tersebut sehingga hasil dari penelitian ini diharapkan akan bermanfaat bagi pihak sekolah dan dapat menjadi data awal bagi penelitian selanjutnya.

\section{METODE PENELITIAN}

Penelitian ini bersifat deskriptif dengan pendekatan cross sectional study, yang dilaksanakan di Sekolah Citra Kasih Manado.Populasi dalam penelitian iniini ialah murid prasekolah Sekolah Citra Kasih Manado usia 2-5 tahunyang berjumlah 63 anak. Sampel penelitian diperoleh dengan metode total sampling sesuai kriteria inklusi yang berjumlah 53 anak. Kriteria inklusi yaitu subjek mengonsumsi susu formula menggunakan botol susu, subjek bersifat kooperatif, dan subjek berada di tempat penelitian saat pengambilan data. Kriteria eksklusi yaitu anggota populasi tidak diizinkan orang tua untuk dijadikan subjek penelitian. 
Instrumen yang digunakan dalam penelitian ini ialah lembar penilaian def- $t$ dan kuesioner. Alat dan bahan yang digunakan dalam penelitian ini ialah sonde, kaca mulut, pinset, nierbeken, masker, sarung tangan, senter, kapas, alkohol 70\%, dan aquades.Pengambilan data dilakukan mengikuti prosedur yaitu pembagian kuesioner kepada orang tua, penjelasan butir-buitr kuesioner kepada orang tua untuk menyatukan persepsi dan pemahaman, pengisian kuesioner oleh orang tua, dan dilanjutkan dengan pemeriksaan def-t pada subjek penelitian. Data diolah dengan menggunakan program komputer Microsoft Office Excel 2010 dan disajikan dalam bentuk tabel distribusi frekuensi kemudian dianalisa berdasarkan hasil persentase.

\section{HASIL PENELITIAN}

\section{Karakteristik subjek penelitian}

Karakteristik subjek penelitian dilihat berdasarkan jenis kelamin, usia, dan pekerjaan orang tua yang dijabarkan dalam Tabel 1-3:

Tabel 1. Distribusi karakteristik subjek penelitian berdasarkan jenis kelamin

\begin{tabular}{ccc}
\hline Jenis kelamin & $\begin{array}{c}\text { Jumlahanak } \\
(\mathrm{n})\end{array}$ & $\begin{array}{c}\text { Persentase } \\
(\%)\end{array}$ \\
\hline Laki-laki & 22 & 42 \\
Perempuan & 31 & 58 \\
Total & 53 & 100 \\
\hline
\end{tabular}

Tabel 1 menunjukkan bahwa anak yang berjenis kelamin laki-laki berjumlah 22 anak (42\%) dan yang berjenis kelamin perempuan berjumlah31anak (58\%).

Tabel 2. Distribusi karakteristiksubjek penelitian berdasarkan usia

\begin{tabular}{ccc}
\hline Usia & $\begin{array}{c}\text { Jumlah anak } \\
(\mathrm{n})\end{array}$ & $\begin{array}{c}\text { Persentase } \\
(\%)\end{array}$ \\
\hline 2 & 6 & 11 \\
3 & 14 & 27 \\
4 & 18 & 34 \\
5 & 15 & 28 \\
Total & 53 & 100 \\
\hline
\end{tabular}

Tabel 2 menunjukkan bahwasubjek penelitian berusia dua tahun berjumlah enam anak (11\%), usia tiga tahun berjumlah 14 anak (27\%), usia empat tahun berjumlah 18 (34\%), dan subjek penelitian berusia lima tahun berjumlah 15 anak $(28 \%)$.

Tabel 3. Distribusi karakteristik subjek penelitian berdasarkan pekerjaan orang tua

\begin{tabular}{ccc}
\hline Pekerjaan & $\begin{array}{c}\text { Jumlah } \\
\text { anak }(\mathrm{n})\end{array}$ & $\begin{array}{c}\text { Persentase } \\
(\%)\end{array}$ \\
\hline PNS & 9 & 17 \\
Wiraswasta & 29 & 55 \\
IRT & 8 & 15 \\
Lain-lain & 7 & 13 \\
Total & 53 & 100 \\
\hline
\end{tabular}

Tabel 3 menunjukkan bahwasubjek penelitian yang orang tuanya bekerja sebagai PNS berjumlah sembilan anak (7\%), wiraswasta berjumlah 29 anak (55\%), ibu rumah tangga (IRT) berjumlah delapan anak (15\%), dan yang termasuk dalam kelompok pekerjaan lainnya (dokter, pengacara, dan notaris) berjumlah tujuh anak (13\%).

\section{Hasil pemeriksaan status karies}

Hasil pemeriksaan status karies diperlihatkan dalam Tabel berikut:

Tabel 4. Distribusi hasil pemeriksaan def- $t$ murid sekolah Citra Kasih Manado

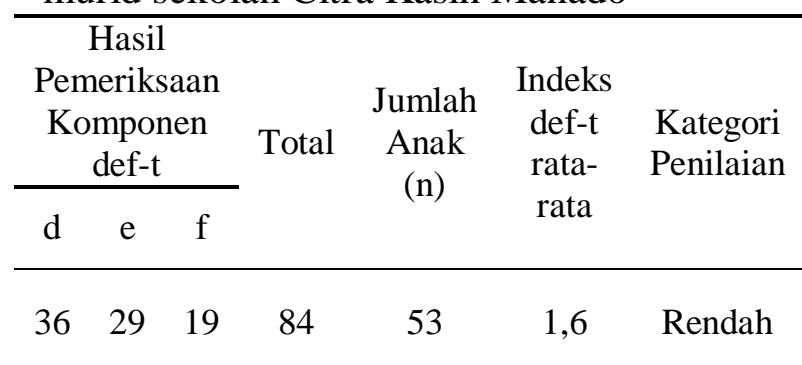

Data hasil pemeriksaan pada Tabel 4 menunjukkan bahwa d (decay) berjumlah 36, e (indicated for extraction) berjumlah 29, dan f (filled) berjumlah 19, dengan indeks def-t rata-rata yaitu 1,6 yang tergolong dalam kategori rendah.

Hasil penilaian status karies berdasarkan karakteristik subjek penelitian dapat dilihat pada Tabel 5-6 berikut: 
Tabel 5. Distribusi hasil pemeriksaan def- $t$ berdasarkan jenis kelamin

\begin{tabular}{|c|c|c|c|c|c|}
\hline \multirow{2}{*}{$\begin{array}{c}\text { Jenis } \\
\text { kelamin }\end{array}$} & \multicolumn{2}{|c|}{$\begin{array}{c}\text { Komponen } \\
\text { def-t }\end{array}$} & \multirow{2}{*}{$\begin{array}{c}\text { Tota } \\
1\end{array}$} & \multirow{2}{*}{$\begin{array}{c}\text { Jumla } \\
\text { h } \\
\text { Anak } \\
(\mathrm{n}=53 \\
)\end{array}$} & \multirow{2}{*}{$\begin{array}{c}\text { Indek } \\
\text { s def- } \\
\text { t rata- } \\
\text { rata }\end{array}$} \\
\hline & d $\quad$ e & $\mathrm{f}$ & & & \\
\hline
\end{tabular}

\begin{tabular}{ccccccc} 
Laki-laki & 9 & 7 & 6 & 22 & 22 & 1 \\
Perempua & 2 & 2 & 1 & 62 & 31 & 2 \\
$\mathrm{n}$ & 7 & 2 & 3 & 62 & & \\
\hline
\end{tabular}

Tabel 5 menunjukkan bahwa komponen ' $d$ ' pada subjek penelitian yang berjenis kelamin laki-laki sebanyak sembilan, komponen 'e' sebanyak tujuh, dan komponen ' $\mathrm{f}$ ' sebanyak enam dengan indeks def-t rata-rata satu dan komponen ' $d$ ' pada subjek penelitian yang berjenis kelamin perempuan sebanyak 27, komponen 'e' sebanyak 22, dan komponen ' $\mathrm{f}$ ' sebanyak 13 dengan indeks def-t ratarata dua.

Tabel 6. Distribusi hasil pemeriksaan def- $t$ berdasarkan usia

\begin{tabular}{|c|c|c|c|c|c|c|}
\hline \multirow{2}{*}{$\begin{array}{c}\text { Usia } \\
\text { (tahun) }\end{array}$} & \multicolumn{3}{|c|}{$\begin{array}{c}\text { Komponen } \\
\text { def-t }\end{array}$} & \multirow{2}{*}{ Total } & \multirow{2}{*}{$\begin{array}{c}\text { Jumlah } \\
\text { Anak } \\
(\mathrm{n}=53)\end{array}$} & \multirow{2}{*}{$\begin{array}{c}\text { Indeks } \\
\text { def-t } \\
\text { rata- } \\
\text { rata }\end{array}$} \\
\hline & $d$ & e & $\mathrm{f}$ & & & \\
\hline 2 & 7 & 6 & 3 & 16 & 6 & 2,7 \\
\hline 3 & 9 & 5 & 2 & 16 & 14 & 1,1 \\
\hline 4 & 10 & 12 & 5 & 27 & 18 & 1,5 \\
\hline 5 & 10 & 6 & 9 & 25 & 15 & 1,7 \\
\hline
\end{tabular}

Tabel 6 menunjukkan bahwa komponen 'd' pada subjek penelitian yang berusia dua tahun sebanyak tujuh, komponen ' $\mathrm{e}$ ' sebanyak enam, dan komponen ' $\mathrm{f}$ ' sebanyak tiga dengan indeks def-t rata-rata 2,7 . Usia tiga tahun memiliki komponen ' $d$ ' sebanyak sembilan, komponen ' $\mathrm{e}$ ' sebanyak lima, dan komponen ' $\mathrm{f}$ ' sebanyak dua dengan indeks def-t rata-rata 1,1 . Usia empat tahun memiliki komponen ' $d$ ' sebanyak 10, komponen 'e' sebanyak 12 , dan komponen ' $\mathrm{f}$ ' sebanyak lima dengan indeks def-t rata-rata 1,5. Usia lima tahun memiliki komponen 'd' sebanyak 10, komponen ' $\mathrm{e}$ ' sebanyak enam, dan komponen ' $\mathrm{f}$ ' sebanyak sembilan dengan indeks def-t rata-rata 1,7 .
Hasil pemeriksaan status karies berdasarkan pola konsumsi susu formula dapat dilihat pada Tabel 7-11:

Tabel 7. Distribusi hasil pemeriksaan status karies berdasarkan lama mengonsumsi susu formula

\begin{tabular}{|c|c|c|c|c|c|c|}
\hline \multirow{2}{*}{$\begin{array}{c}\text { Pola } \\
\text { Konsum } \\
\text { si Susu } \\
\text { Formula }\end{array}$} & \multicolumn{3}{|c|}{$\begin{array}{c}\text { Komponen } \\
\text { def-t }\end{array}$} & \multirow{2}{*}{ Total } & \multirow{2}{*}{$\begin{array}{c}\text { Jumlah } \\
\text { Anak } \\
(\mathrm{n}=53)\end{array}$} & \multirow{2}{*}{$\begin{array}{c}\text { Inde } \\
\text { ks } \\
\text { def-t } \\
\text { rata- } \\
\text { rata } \\
\end{array}$} \\
\hline & d & e & $\mathrm{f}$ & & & \\
\hline $\begin{array}{l}\leq 2 \\
\text { tahun }\end{array}$ & 9 & 7 & 4 & 20 & 11 & 1,8 \\
\hline $\begin{array}{l}>2 \\
\text { tahun }\end{array}$ & 27 & 22 & 15 & 64 & 42 & 1,5 \\
\hline
\end{tabular}

Tabel 7 menunjukkan bahwa komponen ' $d$ ' pada subjek penelitian yang mengonsumsi susu formula $\leq 2$ tahun sebanyak sembilan, komponen 'e' sebanyak tujuh, dan komponen ' $\mathrm{f}$ ' sebanyak empat dengan indeks def-t ratarata 1,8 dan komponen ' $d$ ' pada subjek penelitian yang mengonsumsi susu formula $>2$ tahun sebanyak 27, komponen 'e' sebanyak 22, dan komponen ' $\mathrm{f}$ ' sebanyak 15 dengan indeks def-t rata-rata 1,5.

Tabel 8. Distribusi hasil pemeriksaan status karies berdasarkan frekuensi pemberian susu formula

\begin{tabular}{|c|c|c|c|c|c|c|}
\hline \multirow{2}{*}{$\begin{array}{c}\text { Pola } \\
\text { Konsum } \\
\text { si Susu } \\
\text { Formula }\end{array}$} & \multicolumn{3}{|c|}{$\begin{array}{c}\text { Komponen } \\
\text { def-t }\end{array}$} & \multirow{2}{*}{ Total } & \multirow{2}{*}{$\begin{array}{c}\text { Jumlah } \\
\text { Anak } \\
(\mathrm{n}=53)\end{array}$} & \multirow{2}{*}{$\begin{array}{c}\text { Inde } \\
\mathrm{ks} \\
\text { def-t } \\
\text { rata- } \\
\text { rata }\end{array}$} \\
\hline & d & e & $\mathrm{f}$ & & & \\
\hline $\begin{array}{l}\leq 3 \text { kali } \\
\text { sehari }\end{array}$ & 17 & 14 & 10 & 41 & 21 & 1,9 \\
\hline $\begin{array}{l}>3 \text { kali } \\
\text { sehari }\end{array}$ & 19 & 15 & 9 & 43 & 32 & 1,3 \\
\hline
\end{tabular}

Tabel 8 menunjukkan bahwa komponen 'd' pada subjek penelitian yang mengonsumsi susu formula $\leq 3$ kali sehari sebanyak 17, komponen 'e' sebanyak 14 , dan komponen ' $\mathrm{f}$ ' sebanyak 10 dengan indeks def-t rata-rata 1,9 dan komponen ' $d$ ' pada subjek penelitian yang mengonsumsi susu formula > 3 kali sehari sebanyak 19, komponen 'e' sebanyak 15, dan komponen 
' $\mathrm{f}$ ' sebanyak sembilan dengan indeks def- $t$ rata-rata 1,3 .

Tabel 9. Distribusi hasil pemeriksaan status karies berdasarkan lamanya mengonsumsi susu formula

\begin{tabular}{|c|c|c|c|c|c|c|}
\hline \multirow{2}{*}{$\begin{array}{l}\text { Pola } \\
\text { Konsum } \\
\text { si Susu } \\
\text { Formula }\end{array}$} & \multicolumn{3}{|c|}{$\begin{array}{c}\text { Komponen } \\
\text { def- } t\end{array}$} & \multirow[b]{2}{*}{ Total } & \multirow{2}{*}{$\begin{array}{c}\text { Jumlah } \\
\text { Anak } \\
(\mathrm{n}=53)\end{array}$} & \multirow{2}{*}{$\begin{array}{c}\text { Inde } \\
\text { ks } \\
\text { def-t } \\
\text { rata- } \\
\text { rata } \\
\end{array}$} \\
\hline & d & $\mathrm{e}$ & $\mathrm{f}$ & & & \\
\hline $\begin{array}{l}\leq 15 \\
\text { menit }\end{array}$ & 20 & 15 & 10 & 45 & 27 & 1,7 \\
\hline $\begin{array}{l}>15 \\
\text { menit }\end{array}$ & 16 & 14 & 9 & 39 & 26 & 1,5 \\
\hline
\end{tabular}

Tabel 9 menunjukkan bahwa komponen 'd' pada subjek penelitian yang menghabiskan susu formula $\leq 15$ menit sebanyak 20, komponen 'e' sebanyak 15 , dan komponen ' $\mathrm{f}$ ' sebanyak 10 dengan indeks def-t rata-rata 1,7 dan komponen ' $d$ ' pada subjek penelitian yang menghabiskan susu formula > 15 menit sebanyak 16, komponen 'e' sebanyak 14, dan komponen ' $f$ ' sebanyak sembilan dengan indeks def- $t$ rata-rata 1,5 .

Tabel 10. Distribusi hasil pemeriksaan status karies berdasarkanada/tidaknya penambahan pemanis pada susu formula

\begin{tabular}{|c|c|c|c|c|c|c|}
\hline \multirow{2}{*}{$\begin{array}{c}\text { Pola } \\
\text { Konsumsi } \\
\text { Susu } \\
\text { Formula }\end{array}$} & \multicolumn{3}{|c|}{$\begin{array}{c}\text { Komponen } \\
\text { def-t }\end{array}$} & \multirow{2}{*}{ Total } & \multirow{2}{*}{$\begin{array}{c}\text { Jumlah } \\
\text { Anak } \\
(\mathrm{n}=53)\end{array}$} & \multirow{2}{*}{$\begin{array}{c}\text { Inde } \\
\text { ks } \\
\text { def-t } \\
\text { rata- } \\
\text { rata }\end{array}$} \\
\hline & $d$ & $\mathrm{e}$ & $\mathrm{f}$ & & & \\
\hline $\begin{array}{l}\text { Ditambahka } \\
\text { n pemanis }\end{array}$ & 16 & 10 & 7 & 33 & 16 & 2,1 \\
\hline $\begin{array}{c}\text { Tidak } \\
\text { ditambahka } \\
\mathrm{n} \text { pemanis }\end{array}$ & 20 & 19 & 12 & 51 & 37 & 1,4 \\
\hline
\end{tabular}

Tabel 10 menunjukkan bahwa komponen ' $d$ ' pada subjek penelitian yang mengonsumsi susu formula dengan penambahan pemanis sebanyak 16, komponen 'e' sebanyak 10, dan komponen ' $\mathrm{f}$ ' sebanyak tujuh dengan indeks def-t ratarata 2,1 dan komponen ' $d$ ' pada subjek penelitian yang mengonsumsi susu formula tanpa penambahan pemanis sebanyak 20, komponen 'e' sebanyak 19, komponen ' $\mathrm{f}$ ' sebanyak 12, dan indeks def-t rata-rata 1,4.

Tabel 11. Distribusi hasil pemeriksaan status karies berdasarkan ada/tidaknya tindakan pencegahan karies setelah mengonsumsi susu formula

\begin{tabular}{|c|c|c|c|c|c|c|}
\hline \multirow{2}{*}{$\begin{array}{c}\text { Pola } \\
\text { Konsum } \\
\text { si Susu } \\
\text { Formula }\end{array}$} & \multicolumn{3}{|c|}{$\begin{array}{c}\text { Komponen } \\
\text { def-t }\end{array}$} & \multirow{2}{*}{ Total } & \multirow{2}{*}{$\begin{array}{c}\text { Jumlah } \\
\text { Anak } \\
(\mathrm{n}=53)\end{array}$} & \multirow{2}{*}{$\begin{array}{l}\text { Inde } \\
\mathrm{ks} \\
\text { def-t } \\
\text { rata- } \\
\text { rata }\end{array}$} \\
\hline & d & $\mathrm{e}$ & f & & & \\
\hline Diberika & & & & & & \\
\hline $\begin{array}{c}\mathrm{n} \\
\text { minum } \\
\text { air putih }\end{array}$ & 2 & 5 & 2 & 9 & 8 & 1,1 \\
\hline $\begin{array}{c}\text { Tidak } \\
\text { diberika } \\
n \\
\text { minum } \\
\text { air putih }\end{array}$ & 34 & $\begin{array}{l}2 \\
4\end{array}$ & 17 & 75 & 45 & 1,7 \\
\hline
\end{tabular}

Tabel 11 menunjukkan bahwa komponen ' $d$ ' pada subjek penelitian yang diberi minum air putih setelah mengonsumsi susu formula sebanyak dua, komponen 'e' sebanyak lima, dan komponen ' $\mathrm{f}$ ' sebanyak dua dengan indeks def-t rata-rata 1,1 dan komponen ' $d$ ' pada subjek penelitian yang tidak diberi minum air putih setelah mengonsumsi susu formula sebanyak 34, komponen ' $\mathrm{e}$ ' sebanyak 24, komponen 'f' sebanyak 17, danindeks def-t rata-rata 1,7 .

\section{BAHASAN}

Hasil pemeriksaan status karies pada anak Sekolah Citra Kasih menunjukkanbahwa indeksdef-t rata-rata anak usia prasekolah Sekolah Citra Kasih yang mengonsumsi susu formulayaitu 1,6, artinya rata-rata setiap anak memiliki 1,6 gigisulung yang rusak atau mengalami karies, termasuk pencabutan akibat karies, telah ditumpatkarena karies serta gigi yang sedang mengalami karies. Berdasarkan kategori penilaian menurut indikator WHO, indeks ini berada pada kategori status karies rendah.

Hasil penilaian status karies berdasarkan jenis kelamin menunjukkan bahwa nilai def-t rata-rata pada anak 
perempuan lebih tinggi dibandingkan pada anak laki-laki. Hal ini disebabkan karena anak perempuan pertumbuhannya lebih cepat dibandingkan anak laki-laki termasuk pertumbuhan gigi, sehingga menyebabkan gigi lebih lama terpapar oleh makanan kariogenik yang meningkatkan angka kejadian karies pada anak perempuan. ${ }^{5}$ Berdasarkan usia diperoleh hasil bahwa anak-anak yang berusia dua tahun di Sekolah Citra Kasih memiliki indeks def-t rata-rata yang lebih tinggi dibandingkan anak-anak yang berusia di atas dua tahun, namun masih tergolong dalam kategori rendah. Hal ini disebabkan karena pada usia dua tahun pertama kehidupan anak, gigi geligi masih sangat peka terhadap kerusakan gigi dan umumnya merupakan akibat dari kebiasaan mengonsumsi susu botol yang salah. ${ }^{6}$

Berdasarkan hasil penilaian status karies murid prasekolah Sekolah Citra Kasih, penulis berasumsi bahwa status karies dengan hasil yang rendah tersebut disebabkan oleh faktor pengetahuan, pendidikan, dan pekerjaan orang tua. Orang tua dengan status pekerjaan bekerja mempunyai tingkat pendidikan dan pengetahuan yang baik dalam meningkatkan status kesehatan anak, sehingga kesehatan gigi dan mulut anak tetap terjaga dan terhindar dari resiko karies yang parah. Menurut penelitian yang dilakukan oleh Tommy pada murid prasekolah IntanPermataAisyiyah, Makam Haji, Kartasura, Sukoharjo pada tahun 2012, menunjukkan tingginyakejadian karies gigi $(92,6 \%)$ pada anak disebabkan karena kesadaran orang tua dalam membiasakan anaknya menjaga kebersihan dan kesehatan gigi dan mulut yang masih kurang, serta cara pemberian susu formula dengan tingkat pengetahuan yang masih kurang menyebabkan anak beresiko tinggi terkena karies dibandingkan ibu yang berpengetahuanbaik. ${ }^{7}$ Demikian juga penelitian yang dilakukan di desa Nguwuk kabupaten lamongan pada tahun 2009, diperoleh hasil bahwa ibu dengan tingkat pengetahuan kurang memiliki anak yang lebih banyak mengalami karies dibandingkan ibu dengan pengetahuan baik. Hal ini disebabkan karena seseorang dengan tingkat pengetahuan baik, lebih mudah dalam menangkap dan menyerap informasi yang diberikan yang bersifat positif tentang susu formula dan kejadian karies dibandingkan seseorang dengan pengetahuan yang kurang. ${ }^{8}$

Selain faktor pengetahuan, pendidikan, dan pekerjaan orang tua, penulis berasumsi bahwa faktor sosial ekonomi keluarga juga sangat memengaruhi status karies pada anak.Anak-anak yang berasal dari keluarga dengan status sosial ekonomi menengah ke atas, memiliki status kesehatan keluarga yang baik.Hal ini disebabkan karena semakin baik status ekonomi suatu keluarga, maka semakin terjamin sarana pelayanan kesehatan yang dipilih. Hal ini sesuai dengan penelitian yang dilakukan oleh Jeiska pada tahun 2012 bahwa status sosial ekonomi keluarga sangat memengaruhi status kesehatan serta perilaku hidup sehat anak, karena faktor yang berperan dalam perilaku orang tua terhadap kesehatan gigi anak khususnya dalam pemilihan pelayanan kesehatan anak ialah sosial ekonomi keluarga. Berdasarkan hasil penelitian Jeiska tersebut, anak dengan status sosial ekonomi orang tua yang tergolong menengah ke atas memiliki status karies yang rendah dibandingkan anak dengan status sosial ekonomi orang tua tergolong menengah ke bawah. ${ }^{9}$

Berdasarkan pola konsumsi susu formula diperoleh hasil bahwa indeks def- $t$ rata-rata terendah berada pada kelompok anak yang mengonsumsi susu formula lebih dari dua tahun, lebih dari tiga kali sehari, lebih dari 15 menit, tanpa penambahan gula, dan disertai pemberian air putih. Pada anak yang mengonsumsi susu formula lebih dari dua tahun (79\%) memiliki indeks def-t rata-rata sebesar 1,5 , sedangkan anak yang mengonsumsi susu formula kurangdariatau dua tahun $(21 \%)$ memiliki indeks def-t rata-rata sebesar 1,8. Berdasarkan frekuensi pemberian susu formula, diperoleh hasil bahwa anak yang mengonsumsi susu formula lebih dari tiga kali sehari $(60 \%)$ memiliki indeks def-t rata-rata sebesar 1,3, 
sedangkan anak yang mengonsumsi susu formula kurang dari tiga kali sehari $(40 \%)$ memiliki indeks def-t rata-rata 1,9 . Pada durasi menghabiskan susu formula, diperoleh hasil anak yang meminum susu lebih dari 15 menit (49\%) memiliki indeks def-t rata-rata 1,5 , sedangkan kurang dari 15 menit $(51 \%)$ memiliki indeks def-t ratarata 1,7.Untuk tindakan pencegahan karies dengan mengonsumsi air putih sehabis minum susu, diperoleh hasil bahwa anak yang diberi minum air putih setelah mengonsumsi susu formula hanya delapan anak $(15 \%)$ dengan indeks def-t rata-rata 1,1 yang merupakan jumlah yang paling sedikit dibandingkan dengan anak yang tidak diberi minum air putih setelah mengonsumsi susu formula yaitu sebanyak 45 anak (85\%) dengan indeks def-t ratarata 1,7 .

Berdasarkan hasil di atas, terlihat bahwa pola konsumsi susu formula yang dipaparkan merupakan pola konsumsi yang kurang tepat, namun memiliki hasil indeks def-t rata-rata terendah. Hal ini disebabkan karena cara penyajian susu formula yang mayoritasnya tidak diberi tambahan pemanis, sehingga memengaruhi status karies anak. Pada penelitian ini, cara penyajian susu formula memperoleh hasil sebanyak 37 anak (70\%) yang mengonsumsi susu formula tanpa tambahan pemanis dengan indeks def-t rata-rata 1,4 sedangkan anak yang mengonsumsi susu formula disertai tambahan pemanis sebanyak 16 anak(30\%) dengan indeks deft rata-rata 2,1. Penambahan pemanis pada penyajian susu formula dapat berpotensi menyebabkan karies. Cairan susu formula yang telah diberi tambahan pemanis ini akan melekat cukup lama pada permukaan gigi sehingga dapat menjadi media pertumbuhan bakteri karena adanya kandungan sukrosa. Selain itu, kandungan laktosa yang terdapat di dalam susu mengakibatkan demineralisasi email semakin cepat sehingga dapat berlanjut menjadi karies. ${ }^{10,7}$ Hal ini didukung oleh hasil penelitian Apsari pada tahun 2011 bahwa penyajian susu formula dengan tambahan pemanis berpotensi menimbulkan karies, karena gula merupakan makanan yang bersifat kariogenik. ${ }^{11}$

Penulis berasumsi bahwa perbedaan yang terdapat pada penelitian ini sesuai dengan hasil di atas bukan hanya disebabkan oleh perilaku orang tua dalam cara penyajian susu formula yang tidak disertai tambahan pemanis, namun hal ini disebabkan juga oleh faktor lain seperti pendidikan, pekerjaan, dan faktor sosial ekonomi orang tua yang turut berpengaruh terhadap status kesehatan gigi dan mulut anak. Anak-anak yang bersekolah di Sekolah Citra Kasih Manado, pada umumnya mempunyai orang tua dengan status pendidikan, pekerjaan, dan sosial ekonomi yang tergolong menengah ke atas sehingga mempunyai pengetahuan yang baik dalam membiasakan anaknya untuk menjaga kebersihan gigi dan mulut sejak dini sehingga anak dapat terhindar dari resiko besar terjadinya karies terutama dalam hal mengonsumsi susu formula. Berdasarkan penelitian yang dilakukan oleh Lilik tahun 2005 di Semarang, membuktikan bahwa faktor pekerjaan dan sosial ekonomi orang tua berhubungan dengan status kesehatan gigi anak mereka. ${ }^{12}$ Hasil ini juga didukung oleh penelitian yang dilakukan di Manado oleh James pada tahun 2013 di kecamatan Tomohon Utara bahwa faktor sosial ekonomi dan pengetahuan yang tepat memengaruhi perilaku kesehatan dalam meningkatkan kesehatan, termasuk kesehatan gigi dan mulut dari anak. ${ }^{13}$

Berdasarkan hasil penelitian ini tingkat pengetahuan, perilaku, pekerjaan, dan status sosial ekonomi orang tua merupakan faktor yang sangat berpengaruh terhadap status karies anak.Pengetahuan orang tua yang tepat memengaruhi perilaku kesehatan keluarga dalam meningkatkan kesehatan khususnya kesehatan gigi dan mulut anak, serta pekerjaan dan status sosial ekonomi yang baik mendukung keluarga dalam memilih sarana pelayanan kesehatan yang lebih baik, sehingga status kesehatan anak tetap terjaga dan terhindar dari risiko karies yang parah. 


\section{SIMPULAN}

1. Status karies anak usia prasekolah Sekolah Citra Kasih Manado yang mengonsumsi susu formula tergolong dalam kategori rendah.

2. Anak yang mengonsumsi susu formula lebih dari dua tahun mempunyai status karies rendah.

3. Anak yang mengonsumsi susu formula dengan frekuensi lebih dari tiga kali seharimemiliki status karies rendah.

4. Anak yang memerlukan waktu lebih dari 15 menit untuk menghabiskan susu formula yang dikonsumsi, memiliki status karies rendah.

5. Anak yang mengonsumsi susu formula dengan ada atau tidaknya penambahan pemanis memiliki status karies rendah.

6. Anak yang mengonsumsi susu formula dengan ada atau tidaknya pemberian air putih setelah mengonsumsi susu formula memiliki status karies rendah.

\section{SARAN}

Bagi pemerintah, kiranya pemerintah lebih memperhatikan masalah kesehatan gigi dan mulut anak, khususnya anak usia prasekolah yang masih sangat rentan terhadap kejadian karies melalui programprogram kesehatan pemerintah seperti penyuluhan, pemeriksaan gigi dan mulut, serta pengobatan gigi dan mulut anak usia prasekolah di kota Manado.

Bagi sekolah, kiranya kepala sekolah serta guru-guru dapat mempertahankan status kesehatan gigi dan mulut anak yang sudah termasuk baik melalui programprogram dari sekolah seperti membentuk unit kesehatan gigi sekolah (UKGS) dan penyuluhan kesehatan gigi dan mulut.

Bagi orang tua, perlu adanya peran orang tua dalam mempertahankan hasil yang sudah tergolong baik ini khususnya dalam mengajarkan anak untukterbiasa memelihara status kesehatan gigi dan mulut sejak dini.

Bagi institusi pendidikan, diharapkan adanya penelitian lebih lanjut mengenai faktor yang berpengaruh terhadap status karies anak usia prasekolah Sekolah Citra Kasih yang mengonsumsi susu formula dengan cakupan yang lebih luas dan metode yang berbeda agar dapat digunakan secara umum dan lebih lengkap dalam pengembangan ilmu kesehatan gigi dan mulut khususnya pada kesehatan gigi dan mulut anak-anak.

\section{DAFTAR PUSTAKA}

1. Bakar A. Kedokteran gigi klinis. Ed 2. Yogyakarta: Quatum Sinergis Media; 2012.p.51-6,76.

2. Sulistyoningsih H. Gizi untuk ksesehatan ibu dan anak. Yogyakarta: Graha Ilmu; 2011.p.2-9.

3. Rudolf. Buku ajar pediatrik. Vol 1. Jakarta: EGC; 2006.p.28-180.

4. Maulani C. Kiat merawat gigi anak. Jakarta: PT Elex Media; 2005.p.72.

5. Mailoa SD. Gambaran karies dan pemberian susu botol pada murid TK di kecamatan Tuminting. Dentire J. Universitas Sam Ratulangi. 2012; 2(1):113-17.

6. Widayanti DM. Hubungan pemberian susu botol menjelang tidur dengan kejadian karies gigi pada balita (2-4 tahun) di paut melati kelurahan Kandangan kecamatan Benowo. Jurnal Kesehatan. Asosiasi Institusi Perguruan Tinggi Tenaga Kesehatan. 2011; 1(1):12-21.

7. Nugroho TA, Kusumawati Y, Raharjo B. Hubungan tingkat pengetahuan dan perilaku orang tua tentang pemberian susu botol dengan kejadian karies gigi pada siswa prasekolah. Jurnal Kesehatan, ISSN 1979-7621, Vol. 5, No. 2, Desember166 2012: 165 - 174.

8. Nora TNS, Mauliyah I, Kusbiantoro D. Hubungan pengetahuan ibu tentang penggunaan susu formula dengan kejadian karies gigi pada balita usia 2-4 tahun di desa Nguwok kecamatan Modo kabupaten Lamongan. Jurnal surya 2010; 5(2):35-43.

9. Tulangow JT. Gambaran status karies murid sekolah dasar negeri 48 manado berdasarkan status sosial ekonomi orang tua. [jurnal online] 2012; [diakses 9 oktober 2014]. Diunduh dari: URL: http://ejournal.unsrat.ac.id.

10. Sutadi H. Penanggulangan karies rampan serta keluhannya pada anak. Jurnal 
Jurnal e-GiGi (eG), Volume 3, Nomor 1, Januari-Juni 2015

kedokteran gigi Universitas Indonesia. 2002; 9(1):5-8.

11. Apsari AR. Hubungan penggunaan susu botol dengan kejadian karies gigi pada siswa TK ABA II Buntalan Klaten Tengah (KTI). Skripsi. Klaten: Sekolah Tinggi Ilmu Kesehatan Muhammadiyah Klaten. 2011.
Oktober 2014]. Diunduh dari: URL: http://eprints.undip.ac.id.

13. Pontonuwu J. Gambaran status karies anak sekolah dasar di kelurahan Kinilow 1 kecamatan Tomohon Utara.E-Gigi. Universitas Sam Ratulangi. 2013 [diakses 9 Oktober 2014]; [7 halaman]. Diunduh dari: URL: http://ejournal.unsrat.ac.id.

12. Hidayati L. Hubungan karakteristik keluarga dan kebiasaan konsumsi makanan kariogenik dengan keparahan karies gigi anak sekolah dasar. Tesis. Semarang: Universitas Diponegoro. 2005. [diakses 9 
Lombo, Mayul, Gunawan: Status Karies Anak... 